Tér és Társadalom 21. évf. 2007/1. 171-176. p.

\title{
KÖNYVJELZÖ
}

\section{KOLOZSVÁRI OLVASMÁNYOK}

\section{KUSZTOR ADÉL}

A határon túli magyar nyelvü felsőoktatás talán legjelentősebb központjában a földrajztudomány is hallható magyarul. A kolozsvári Babeş-Bolyai Egyetem földrajz szakának magyar nemzetiségü diákjai anyanyelvükön tanulhatják mindazokat a tantárgyakat, amelyeket magyar tanáraik adnak elő nekik. Az egyetem magyar nemzetiségú tanárai között pedig a romániai geográfia jeles képviselőit találjuk. Annak ellenére, hogy a romániai földrajzosok elsődleges profilja még ma is a természetföldrajz, a feltörekvő fiatalok között egyre több a társadalomföldrajz különböző területeinek magasan képzett müvelöje. A földrajz szakos hallgatók összesített száma is folyamatosan nő, számuk évfolyamonként már meghaladja a száz föt, ugyanis a magyarországi - és más dél-, kelet- és közép-európai - felsőoktatási változásokhoz hasonlóan Kolozsváron is évröl évre egyre többek számára nyílnak meg az egyetem kapui. A hallgatói létszámhoz viszonyítva az oktatók aránya egyre kisebb - ebböl a szempontból a magyar nemzetiségü diákság helyzete kedvezöbb, mert a magyar nyelvü órákat a tömegképzés áramában ök kisebb csoportokban, ember(tanár)közelibben tanulhatják.

A nemzetiségi diákok anyanyelvű képzésének támogatására a Babeş-Bolyai tanárai saját jegyzeteket készítenek magyarul, amelyek beilleszkednek az egyetemi földrajzoktatás tantervi struktúrájába. Megjelenésük viszont nemcsak a magyar nyelven folyó oktatás erösítésére szolgál, hanem a romániai magyar nyelvü földrajztudomány fejlödésére is.

Az általános földrajz témakörében kötelező tantárgyként Kovács Csaba Miklós Általános népességföldrajzával (Presa Universitară Clujeană, 2006, Kolozsvár) találkoznak a diákok. A részdiszciplína általános, bevezető jellegénél fogva a jegyzet első oldalain a népességtudományok és a földrajz kapcsolata bontakozik ki. A népesedési elméletek bemutatásával alapvetỏ szociológiai fogalmak kerülnek tisztázásra, miközben a népességföldrajz sajátos szemlélete is kikristályosodik. A népesedési elméletek kapcsán szó esik közgazdaságtani megközelítésről (pl. Smith, Ricardo), Malthus klasszikus elméletéről, majd a demográfiai átmenet elemzése során a mai társadalmak összetételének területi sajátosságairól is beszél a szerző, rávilágítva a térbeli egyenlötlenségek szerepére a népesedési folyamatok terén. A népesedési elméletek fejlődésébe ágyazva a földrajztudomány történetéből is kapunk egy szeletet, az emberföldrajz megjelenésétől a modern társadalomföldrajzi elemzésig. 
Az ember (Homo sapiens) kifejlödését és földi elterjedését hosszú oldalakon követhetjük végig. Az evolúciós elmélet alakulását, eredményeit, kérdőjeleit, a föemlösök evolúciójának fázisait földrajzosok számára már-már biológiaipaleontológiai részletességgel olvashatjuk. Kontinensről kontinensre járhatunk a mai ember nyomában térbeni-időbeli elterjedését vizsgálva, ezzel együtt a mai népcsoportok eloszlására is magyarázatot kapunk.

A népesség területi eloszlását, a népsürüség globális különbségeit részletezö fejezet számba veszi azokat a természeti-társadalmi tényezőket, amelyek befolyásolják a népesség térbeli elterjedését és a társadalmak eltérő müködését, újabb példákkal alátámasztva népességföldrajz és egyéb tudományágak szoros kapcsolatát. Megtaláljuk ebben a részben a legfontosabb témához kapcsolódó demográfiai fogalmak (lakónépesség, állandó népesség stb.) definíció jellegü magyarázatát, ahogy a további fejezetekben is a vonatkozó fogalmakat, például a népesség dinamikájához kötődően a termékenységi, halálozási, szaporodási mutatók leírását, kiszámítási módját. Egyetemi jegyzetként így a könyv teljesítette legfontosabb feladatát, alaposan tisztázta, kontextusba helyezte a szakkifejezéseket, példákkal támasztotta alá a bemutatott jelenségeket.

Olvashatunk a világnépesség számbeli fejlődéséről, az ezekkel kapcsolatos előrejelzésekröl, a lehetséges következményekröl, majd a népesség nemek, korcsoportok, családi állapot szerinti szerkezetéröl. A világ társadalmaiból merített tipikus példák mellett Románia népességföldrajzi viszonyiról is képet kapunk.

A népesség társadalmi-gazdasági helyzetéről szóló fejezeten belül kerül sor a lakosság településtípusok szerinti eloszlásának, etnikai, vallási csoportjainak bemutatására, a nagyrasszok, rasszok földrajzi elterjedésének, valamint a foglalkozási szerkezet legfontosabb jellemzőinek (úgymint gazdasági aktivitás, foglalkozási ágak, munkanélküliség) ismertetésére. Az utolsó fejezet a népesség mobilitásával foglalkozik. Az alapvető fogalmak (vándorlási különbözet, fluktuációs mérték stb.) magyarázata után a migráció motivációs hátterének különböző elméleteit ismerhetik meg a diákok, majd a jelenkori migrációs folyamatok legfontosabb jellemzőit.

A jegyzet böséges összefoglalója a népességföldrajzi ismereteknek. Szerepel benne a diszciplína minden lényeges momentuma, néhol részletezettségében túl is nyúlik tankönyvi szerepén. Fontos érdeme, hogy nem szorítkozik kizárólag a földrajzi aspektusokra, hanem a jelenségek magyarázatánál kitér a kapcsolódási pontokon más társadalom- vagy éppen természettudományok felé.

Nagy Egon: Az Európai Unió földrajza (Presa Universitară Clujeană, 2006, Kolozsvár) címú jegyzete kisebb terjedelmü egyetemi tankönyv - bár oldalszámát igencsak befolyásolja az apró betüméret. A kisebb terjedelmet persze az is magyarázza, hogy a tantárgyi felosztás szerint az Európai Unió földrajza az Európa regionális földrajza címú tárgy mellett kerül oktatásra, amely pedig magában foglalja a kontinens természetföldrajzi adottságainak és az egyes országok regionális földrajzának tanítását. Ebben a könyvben tehát nem volt szükség a domborzati viszonyok országonkénti ismertetésre. Ez azonban nem tette könnyebbé a szerzö dolgát. Mi marad tehát, amit az integráció területi viszonyairól el lehet mondani? Az unió 
Tér és Társadalom 21. évf. 2007/1. 171-176. p.

egészéröl, mint egységes területi entitásról szól tehát a könyv, felülemelkedve az alkotó államok sajátos vonásain, egyedi jellegzetességeiken. Az EU-n belüli területi egyenlötlenségek alapjául sem a nemzetek, hanem a régiók szolgálnak.

A tankönyv szinte kötelező részeként szerepel az integráció születésének, fejlödésének története, amit az egyetemi oktatásban rögtön ki is lehet egészíteni a bóvítési folyamat legújabb fázisával. Mára már az időközben tagországgá vált Románia számára is alapvető ismereteket jelent az Európai Unió története és müködése.

Mégsem maradt ki teljesen a leírásból a természeti viszonyok rövid bemutatása, mindez azonban - mint az EU rendelkezésére álló természeti eróforrások egyuittese -, a versenyképesség és a gazdasági fejlödés tükrében történik. Ugyanígy, az integráció egészének jövőjét, társadalmi-gazdasági fejlödését szem előtt tartva részletesen foglalkozik a tankönyv a népesség különbözö tulajdonságok szerinti eloszlâsával (pl. vallásosság), a városodás folyamatával, migrációs tendenciákkal, demográfiai folyamatokkal (elsősorban az elöregedés problémájával). Külön fejezetet kapott az EU két, talán leghangsúlyosabb közös politikája: a mezógazdasági politika és a regionális politika. Ezek mellett a szerző az ipari szerkezetváltást és következményeit, valamint a szolgáltatási szektor növekvő szerepét (közlekedési fejlesztések, idegenforgalom) emeli ki külön részben.

Böséges adatbázissal szolgál a tankönyv, egészen részletes táblázatokat találunk például a városodás tendenciái, a mezőgazdaság egyes területei (erdősültség, búzatermelés stb.), infrastrukturális ellátottság, a kereskedelmi tevékenység mutatóiról.

Az Európai Unió területi egyenlőtlenségeinek elemzésekor a szerző elsődleges kérdése a versenyképesség megvalósulása. Ez az integráció egyik legfontosabb célja is, az egyes múködési területek esetében kitüzött politikák ennek a célnak vannak alárendelve. Ebböl a nézőpontból a szerző folyamatosan értékeli is az EU gazdaságitársadalmi folyamatait és az irányító politikákat. Mindenekelőtt az agrárpolitikát kritizálja, mert szerinte az az integráció gazdasági fejlödésének legnagyobb gátja.

Az utolsó fejezet az unió belső kohéziójáról, a világgazdaságban elfoglalt helyéről és jövőjéről szól. Kétségeit, kritikáit fogalmazza meg a szerző az uniós politikákkal szemben. Úgy gondolja, az Európai Unió versenyhátrányban van a világgazdasági triád másik két tagjával - Japánnal és az Egyesúlt Államokkal - szemben, és nem is a legjobb utat választotta a hátrány ledolgozása érdekében. Csokorba szedve olvashatjuk itt azokat a legfontosabb rizikótényezőket, amik az EU jövőbeni fejlődésének gátjai lehetnek. Ezek közül a geopolitikai-stratégiai tényezők között szerepel az unió nemzeti, nemzetállami széttagoltsága, a jövőbeni bővítés vegyes megítélése, kérdéses hatásai, az egyes tagállamok politikai önállósághoz való ragaszkodása, az összehangolt külpolitika hiánya, valamint a hiányzó kỏzỏs stratégiai-védelmi koncepció. A gazdasági tényezők kulcsfogalmai a versenyképesség és a szolidaritás, ezek megvalósulásában az EU-t mind Japán, mind az USA megelözi. Ennek legfontosabb okait a következókben látja a szerző: a kutatás-fejlesztési szektor elhanyagolása, a relatíve kevés munkaórák száma, a lakosság elöregedése, a munkaerő kisebb mértékủ mobilitása (ami a keleti bővítéssel csak fokozódott), a közös gazdasági törvénykezés valós gyakorlatának hiánya, az államháztartási reformok halogatása mind a tagállamok, 
Tér és Társadalom 21. évf. 2007/1. 171-180. p.

mind a közösség szintjén. Mindezek olyan problémás területei az Európai Unió működésének, amik átgondolása nélkül a gazdasági fejlődés további útja is veszélyben forog, a világgazdasági centrumoktól való lemaradás pedig prognosztizálható.

A terület- és településfejlesztő geográfusok alapvető szakmai tankönyve Benedek József: Területfejlesztés és regionális fejlödés (Presa Universitară Clujeană, 2006, Kolozsvár) címü munkája.

A tankönyv elméleti hátterében ott találjuk a regionális gazdaságföldrajz, regionális gazdaságtan, regionális tudomány alapjait, a klasszikus gazdasági, gazdaságföldrajzi megközelítéstöl végigvezetve napjaink regionalizált gazdaságirányításának világába. A száraz elméleti részek között szakmai elöképzettség hiányában még nehéz eligazodni, ebben segít a diákoknak könyv világos szerkezete, átlátható szerkesztése. A területfejlesztés gyakorlatát a regionális növekedés különböző elméleteivel alapozza meg, és ezeket az elméleteket állandóan szem elött tartva magyarázza azt. A tényleges fejlesztési programok megvalósulása, a gyakorlati munka az elmélet mellett kicsit háttérbe szorult, de a böséges európai és hazai (romániai) példákkal való szemléltetés mégis életközelibbé teszi a teóriákat.

A tankönyv első fele tiszta elmélet. Elöször interdiszciplináris jellegükben magyaráz és tudománytörténeti kontextusba helyez olyan alapvető fogalmakat, mint a tér, a területpolitika, telephely, térszerkezet, térbeliség, régió, regionalizálás stb. A klasszikus telephelyelméletektől (pl. központi helyek elmélete) kiindulva eljutunk az új gazdaságföldrajz modern szemléletéhez. A regionális növekedés tényezőinek számba vétele után a különbözö fejlődéselméletek ismertetése következik, mint a neoklasszikus, új (endogén), poszt-keynes-i elméletek, az exportbázis elmélete, a polarizációs vagy fủggőségi, az evolucionionista-történelmi elméletek, a reguláció elmélete, a dinamikus fejlődési elméletek és az új regionalizmus.

A második részben a területfejlesztés gyakorlati oldaláról közelítïnk, például véve a romániai gyakorlatot, és két területi szinten vizsgálhatjuk meg a területfejlesztés egyes részfolyamatait. Állami szinten a Nemzeti Fejlesztési és a Nemzeti Területfejlesztési Tervvel ismerteti meg a leendő szakembereket a szerzö. A hivatalos dokumentumot értékeli, magyarázatokkal, kiegészítésekkel és módosító javaslatokkal látja el. A Nemzeti Fejlesztési Terv és a Regionális Fejlesztési Tervek ismertetése közben világossá válik a területfejlesztés gyakorlati menete a dokumentációs fázistól (törvényi keretek, területfejlesztési politikák letétele) a helyzetelemzésen, a diagnózis megállapításán (problémák feltárása), a javaslattétel megtételén (stratégiák, cselekvési programok, prognózisok, pénzügyi tervezés) át az alkalmazásig, majd az ellenőrzés, monitorizálás fázisáig. Részletesen olvashatunk a Nemzeti Területfejlesztési Tervröl, mint a romániai területfejlesztés legfontosabb dokumentumáról, amiből a területfejlesztési politika legfőbb prioritási területei kiviláglanak.

Külön fejezetet kapott a romániai sajátos problémákkal küzdő régiók bemutatása, mint a régi ipari és innovatív régiók, valamint ezek lehatárolásának problémái. Ezután a hátrányos helyzetủ és támogatott övezetek jellemzése következik, hiszen a támogatásra szoruló területek kijelölése a területfejlesztés kiemelt feladata. Romániában ún. ipari szerkezetváltási övezeteket (összesen 11 darabot) határoz meg a 
Nemzeti Területfejlesztési Terv, amelyek a PHARE 2001 programból kaptak támogatást. Ezeknél a fennálló problémák és a meglévő fejlesztési lehetỏségek felmérése volt egy igen fontos feladat. Ezeket a régiókat a szerzỏ részletesen bemutatja a tankönyvben, az eredeti fejlesztési dokumentumban leírtakat kiegészítve és javítva.

A következő fejezet a Nemzeti Területfejlesztési Terv meglévő részeinek bemutatása, úgymint a közlekedési útvonalak, a vizek, a védett területek, a településhálózat és a természeti kockázati területek (környezetszennyezés által veszélyeztetett területek) részei. Ezek egyben jelzik a román területfejlesztés legfontosabb célterületeit. A következőkben kidolgozásra kerül még a turizmussal és a vidékfejlesztéssel foglalkozó fejezet.

A regionális területfejlesztés három modelljét mutatja be a szerző: a német, a brit és a francia modell mủködésének ismertetése után tér rá a Romániában - vagy akár más átalakuló kelet-európai országban - alkalmazható fejlesztési módra. A 8 román fejlesztési régió területfejlesztési tervének legfontosabb tartalmi egysége az adott területen észlelt problémák, zavarok feltárása és a megoldások, javaslatok tétele a társadalom-gazdaság egyes szakterületein (szakdoménium) belül.

Ezt követően a regionális fejlesztései stratégiák felsorolása következik. Ezek azok a stratégiák, amelyek közül a szakembereknek ki kell választaniuk a legmegfelelőbbet, ami az aktuális probléma megoldásához vezet az adott területi viszonyoktól függöen. Ez az, amit a területfejlesztőnek szem elött kell tartania, és megfelelö felkészültséggel választani. Az itt bemutatott stratégiák - az integráció vagy lekapcsolás stratégiája, a kiegyensúlyozott funkcionális terek vagy a munka funkcionálisterületi megosztásának stratégiája, a növekedési pólusok elmélete, a keresleten és a kínálaton alapuló regionális stratégia technológiai parkok vagy az endogén regionális fejlesztés stratégiája. Az egyes stratégák bemutatásán túl a szerzỏ a helyi - vagy a romániaihoz hasonló problémákkal küzdő kelet-európai - viszonyokhoz való alkalmazhatóságot is vizsgálja, segítve ezzel a leendő szakemberek mérlegelését.

Románia területi fejlettségének egyenlötlenségei nem elhanyagolhatóak, az egyes régiók és megyék közötti különbségek - elsősorban történelmi-gazdasági meghatározottság alapján - éles fejlődési törésvonalakat rajzolnak ki. A fejlettség csúcsán az országon belül a fỏváros és régiója áll, majd a Bánát és Erdély délkeleti része követi. Komoly elmaradást szenvednek az ország keleti részén fekvö moldvai régiók. Az Európai Unióhoz történt 2007. január elsejei csatlakozás a romániai területfejlesztést is több lehetöséghez juttathatja, de a megoldás kulcsa a szakértők kezében marad. A regionális különbségek csökkentése az integráción belül is a területfejlesztő szakemberek megoldásaira vár. 
Tér és Társadalom 21. évf. 2007/1. 171-180. p.

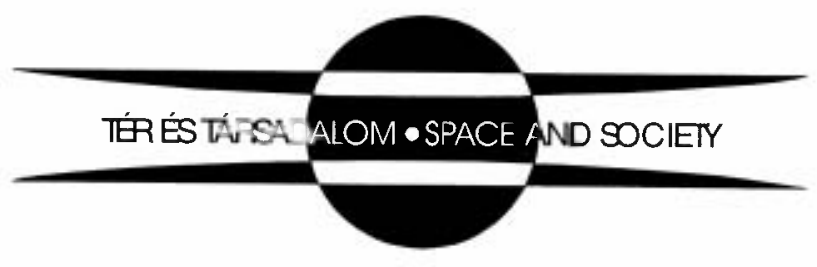

